\title{
STUDY OF STONE QUARRYING AND SILICOSIS IN JODHPUR DISTRICT
}

\author{
Purnima Singh \\ Assistant Professor (Geography) \\ Government Meera Girls College, Udaipur (Rajasthan), India \\ Email: purnimasinghbunkar@gmail.com
}

\begin{abstract}
Jodhpur is one of important stone quarrying district in Rajasthan. Silicosis is an occupational disease found among stone quarrying workers. The research paper is based on secondary data. Workers are mostly from deprived and economically weaker sections of society. Due to illiteracy and lack of awareness, workers do not use protective equipments. Long exposure to silica causes incurable silicosis. More than 3600 silicosis patients have been identified in Jodhpur district. Prevention is only cure for silicosis. Spread of awareness and use of protective equipments and better management of disease is suggested.
\end{abstract}

Key words: Silicosis, Quarrying, Sandstone, Environment, Occupational Disease, Minerals.

\section{Introduction}

Man interacts with his surrounding environment to form new environs. Mining is one of the oldest occupations of mankind, next only to hunting, gathering and domestication of plants and animals. Diseases which are caused due to working environment at work place are called occupational diseases. Silicosis develops to the workers of stone industry due to exposure to silica. Silicosis is a form of occupational lung disease which is caused by inhalation of crystalline silica dust. It is a type of pneumoconiosis, characterised by inflammation and scarring in the form of nodular lesions in the upper lobes of the lungs. Signs and symptoms of silicosis are shortness of breath, cough, fatigue, chest pain, loss of appetite, fever and cyanosis (blue skin). In Jodhpur district 408 people have died due to silicosis during last five years. Silicosis is a permanent and incurable disease. Treatment options currently available focus on controlling the symptoms and preventing any further progress of the condition. Because of exposure to silica dust, silicosis is an occupational hazard to workers of mining, sand blasting, quarrying, ceramics and foundry industry as well as grinders, stonecutters, refractory brick workers, Tomb Stone workers, poetry workers and others.

\section{Review of Literature}

Various researches including researchers from the Desert Medicine Research institute, Jodhpur studied about silicosis in Jodhpur and in Rajasthan. National Institute of Occupational Health, Ahmadabad also conducted a study about silicosis among mining workers in 2009 in Rajasthan. Ahmad, Absar (2015) studied Silicosis, Mining and Occupational Health in India's Sandstone Industry. Anand, PK; Singh, Himmat; Yadav, Dr S.P. (2011) studied awareness and practices about silicosis among the sandstone Quarry workers in desert ecology of Jodhpur, Rajasthan, India. Nabdi, Subroto; Burnase, Nisant; Barapatre, Anand and others (2018) studied assessment of Silicosis awareness among stone mine workers of Rajasthan State. Sahu, Anand P.; Saxena, Ashok K. (1994) studied on Enhanced Translocation of Particles from Lungs by Jaggery and it was published in Environmental Health Perspectives.

\section{Objectives of Study}

The present study aims to identify the distribution of stone quarrying centres in Jodhpur district and to understand the occurrence of silicosis in the workers and to suggest the preventive and remedial measures for avoiding disease and to examine the monetary relief granted by state government to silicosis affected patients.

\section{Methodology}

The study is based on unpublished and published secondary data collected from various government departments. The data has been suitably analysed to draw meaningful results. 


\section{Study Area}

Jodhpur District is located in western part of Rajasthan between $26^{\circ} 00^{\prime}$ North and $27^{\circ} 37^{\prime}$ North latitudes and from $72^{\circ} 55^{\prime}$ East and $73^{\circ} 52^{\prime}$ East longitudes spreading over an area of 22,850 $\mathrm{km}^{2}$. The district is situated at an altitude of $250-300 \mathrm{~m}$ above sea level. Jodhpur district comprises of three distinct physiographic units: - the Alluvial Plains, Sand dunes and escarpments.

\section{Figure 01: Location Map of Jodhpur District}

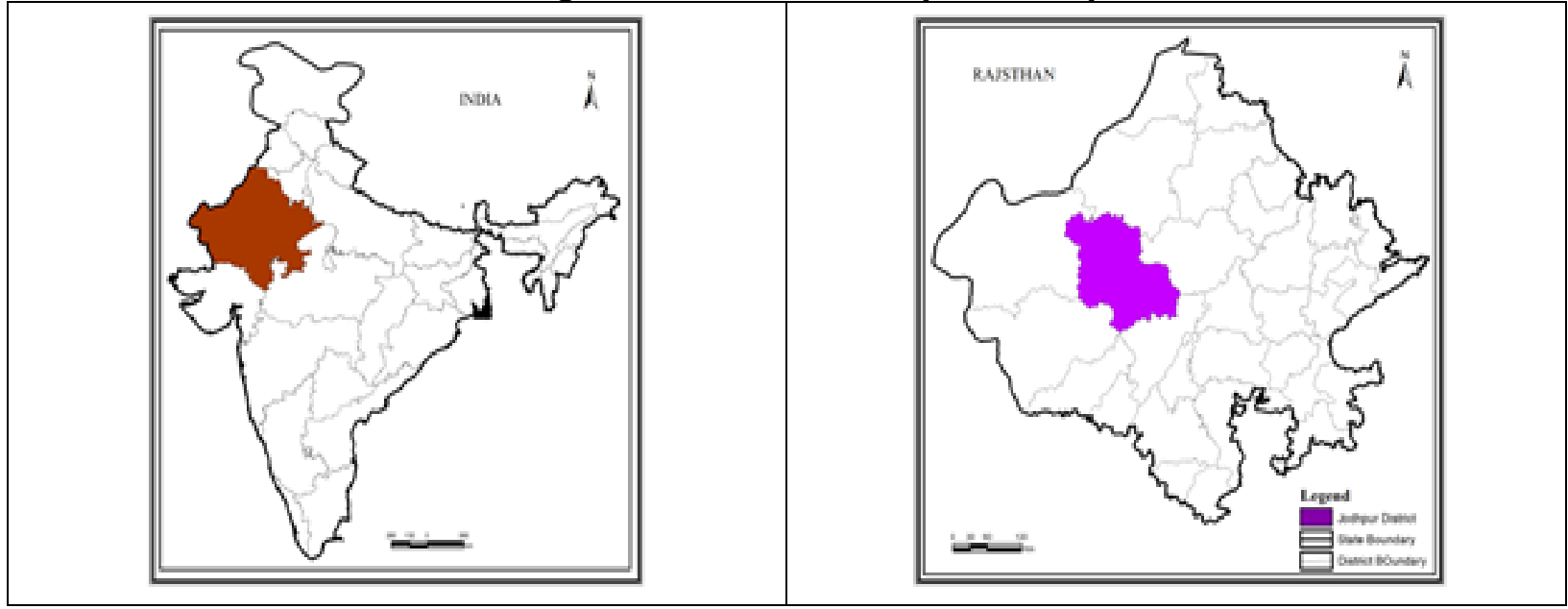

\section{RESULTS AND DISCUSSION}

\section{Distribution of Stone Quarrying}

Jodhpur is one of the prominent nerve centres of Sandstone mining in Rajasthan. Sandstone is quarried at a number of places, important among them are Fidusar, Soorsagar, Brahmno Ka Tanka, Mandore, Balsamand, Kaliberi, Bhuriberi, Keru, Beru, Decha, Sergarh, Chokri, Kasti, Bhopalgarh, Ratri, Setrawer, Barli, Balesar, Satrave, Ketu, Blalu etc. in the district. Fawn and red coloured sandstone of the district is very popular and found in abundance, Besides Sandstone, limestone, Quartz, dolomite and other building stones, stone slabs and flagstone are mined in the district. The minor minerals mined in Jodhpur district include sandstone, masonry stone, limestone, granite, rhyolite, marble, gravel etc.

Figure 02: Mineral Map of Jodhpur District

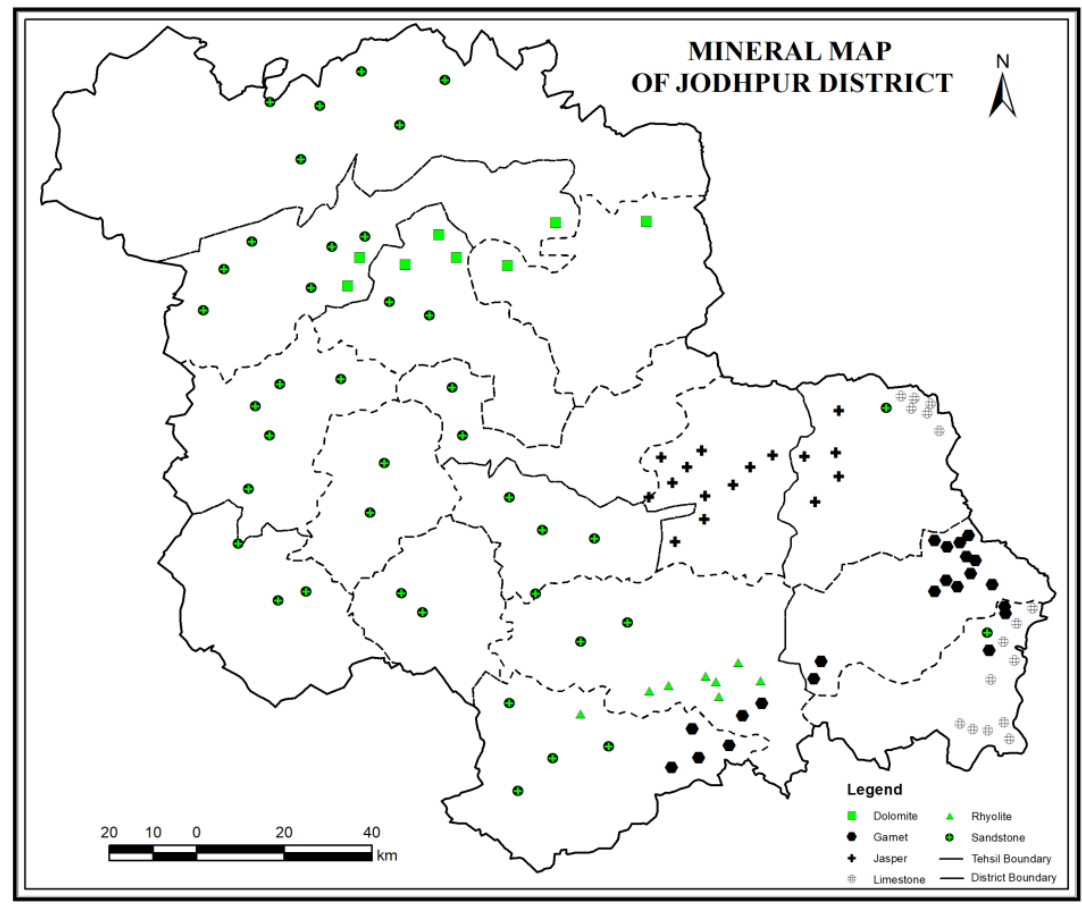


The following table gives data of mining of minor minerals in Jodhpur which are dominated by Sandstone and masonry stone.

Table 01: No. of Mineral Leases, Area, Production and no. of People Employed

\begin{tabular}{|l|c|c|c|c|c|c|}
\hline Year & $\begin{array}{c}\text { No. of } \\
\text { Mineral } \\
\text { Leases }\end{array}$ & $\begin{array}{c}\text { Area } \\
\text { (hectares) }\end{array}$ & $\begin{array}{c}\text { Production } \\
\text { (in lakh } \\
\text { tonnes) }\end{array}$ & $\begin{array}{c}\text { Sale Value } \\
\text { (Crores Rs.) }\end{array}$ & $\begin{array}{c}\text { Employment } \\
\text { (No.) }\end{array}$ & $\begin{array}{c}\text { Revenue } \\
\text { (in Crores) }\end{array}$ \\
\hline $2013-14$ & 501 & 1772.67 & 159.53 & 343.49 & 39050 & 105.5 \\
\hline $2014-15$ & 509 & 1777.62 & 180.99 & 381.21 & 39603 & 106.33 \\
\hline $2015-16$ & 498 & 1777.67 & 164.23 & 405.12 & 39432 & 136.46 \\
\hline $2016-17$ & 488 & 8963.89 & 153.01 & 402.43 & 40857 & 146.26 \\
\hline $2017-18$ & 542 & 8368.30 & 161.63 & 443.99 & 44221 & 167.65 \\
\hline
\end{tabular}

Source: Department of Mines and Geology, Government of Rajasthan, Udaipur

It is clearly seen that more than 44 thousand people are employed in mining activities in the district. This figure is almost stable around 40 thousand if Baji mining is excluded. If we exclude Bajri then the total mining lease area is 1777.67 hectares. Mineral leases are also around 500. Revenue generated in last five years has increased from 105.5 crores to 167.65 crores.

\section{Distribution of Silicosis and Preventive Measures}

The pneumatic hammer drill and sandblasting both have significantly contributed for occurrence of silicosis. For diagnosis of silicosis, patient should have history of exposure to silica, chest imaging that reveals findings and such symptoms should not be caused by any other disease in the patient. There are 221 mining leases of sandstone and masonry stone alone which employ 37 thousand workers. Stone Mining is unorganised sector hence welfare of mine workers is not a priority for mine owners and government. There are about 1268 stone based industrial units in district. There is a cluster of stone processing centres in Mandore, Soorsagar, Osian and Jodhpur city with about 116 industrial units of stone processing. Working conditions are poor and respiratory equipments are rarely used. Most of the workers belong to scheduled caste and majority are of age group 20-40 years. They have poor awareness about causation and prevention of silicosis. Mine owners do not generally follow mine safety rules and norms and are less concerned about health and wellbeing of mine workers. Total 2166 silicosis patients were granted relief of Rs. 1 lakh each by state government while family of 408 workers who died due to silicosis were provided assistance of Rs. 3 lakh each.

Table 02: Silicosis Patients and Relief Distributed in Jodhpur District

\begin{tabular}{|c|c|c|c|c|c|c|c|}
\hline \multirow[t]{2}{*}{ \# } & \multirow[t]{2}{*}{ Year } & \multirow{2}{*}{$\begin{array}{l}\text { Patients } \\
\text { identified } \\
\text { by Board }\end{array}$} & \multirow{2}{*}{$\begin{array}{c}\text { Amount } \\
\text { Received } \\
\text { (in Lakhs) }\end{array}$} & \multicolumn{4}{|c|}{ Payments distributed to silicosis patients (No.) } \\
\hline & & & & Patients & $\begin{array}{c}\text { Amount } \\
\text { (in Lakhs) }\end{array}$ & Deceased & $\begin{array}{c}\text { Amount } \\
\text { (in Lakhs) }\end{array}$ \\
\hline 1 & $2012-13$ & 7 & 21 & - & - & 7 & 21 \\
\hline 2 & 2013-14 & 118 & 31 & 25 & 25 & 02 & 06 \\
\hline 3 & 2014-15 & 382 & 306 & 201 & 201 & 35 & 105 \\
\hline 4 & $2015-16$ & 1540 & 391 & 235 & 235 & 52 & 156 \\
\hline 5 & $2016-17$ & 958 & 1684 & 1285 & 1285 & 133 & 399 \\
\hline 6 & $2017-18$ & 599 & 957 & 420 & 420 & 179 & 537 \\
\hline & Total & 3604 & 3390 & 2166 & 2166 & 408 & 1224 \\
\hline
\end{tabular}

Source: District Collectorate, Jodhpur

Total budget allotted by Rajasthan Environment and Health Administration Board (REHAB) was Rs. 3390 lakhs and by Chief Minister' s Relief Fund (CMRF) was Rs. 63 lakhs making grand total of Rs. 3453 Lakhs. Precaution is the best way to prevent silicosis. To prevent silicosis work place activities that produce respirable crystalline silica dust are to be identified and then dust is to be eliminated or controlled. Water spray should be used where dust emanates. Dust can also be controlled through dry air filtering. Eating of jaggery also helps prevent silicosis. There is need of strict implementation of mining rules and regulations for maintaining good environment at mine site. Wet drilling, water sprinkling on haul road surface, use of preventive equipments like Putting mask or wet cloth on mouth and nose by mine workers and wet drilling prevents inhalation of silica particles and hence can prevent silicosis. Regular health check up of mine workers should be ensured. Non Governmental Organisations 
(NGOs) like Mine Labour Protection Campaign (MLPC) are working for the welfare of mining workers and silicosis affected people.

\section{Conclusion}

A large number of silicosis patients have been detected among the stone quarrying and processing workers in the district of Jodhpur. Prevention is only cure for silicosis. The level of awareness is poor among workers. Workers are mostly from vulnerable sections of society. State government is providing monetary relief to silicosis affected and to the kin of those who have died due to silicosis. There is need for increasing awareness among mining workers for using protective equipments and for providing better health care facilities to silicosis patients. There is urgent need for strict enforcement of rules and regulations by concerned agencies for environmental sustainable mining and for prevention of silicosis.

\section{Acknowledgment: ICSSR}

\section{References}

1. Ahmad, Absar (2015) Silicosis, Mining and Occupational Health in India's Sandstone Industry. EHS Journal.

2. Anand, P K; Singh, Himmat; Yadav, Dr S.P. (2011) Awareness and practices about silicosis among the sandstone Quarry workers in desert ecology of Jodhpur, Rajasthan, India. Research Gate.

3. Nabdi, Subroto; Burnase, Nisant; Barapatre, Anand and others (2018) Assessment of Silicosis awareness among stone mine workers of Rajasthan State.

4. Sahu, Anand P.; Saxena, Ashok K. (1994) Enhanced Translocation of Particles from Lungs by Jaggery published in Environmental Health Perspectives.

5. Singh, Purnima (2017) Effects of Asbestos mining and related activities on human health: A case study of Udaipur district, Annals of RGA, Volume 34. Bhilwara. 